\title{
RELATIONSHIP AMONG TREE CANOPY QUANTITY, COMMUNITY DEMOGRAPHICS, AND TREE CITY USA PROGRAM PARTICIPATION IN MARYLAND, U.S.
}

\author{
By Michael F. Galvin ${ }^{1}$ and David Bleil ${ }^{2}$
}

\begin{abstract}
The Tree City USA (TCUSA) program is a national program in the United States that provides recognition to communities that meet certain standards, including having a tree ordinance and spending at least US $\$ 2.00$ per capita on urban forestry. Census data for 2000 were combined with records on TCUSA program participation and tree canopy cover data for 74 communities in Maryland, U.S., to ascertain relationships among tree canopy quantity, community demographics, and Tree City USA program participation. Communities participating in TCUSA had widely varying demographics (2.2\% to more than $97 \%$ nonwhite) but tended to have larger overall populations and larger nonwhite populations than did nonparticipating communities, with the percentage of nonwhite population slightly higher for nonparticipants. Multivariate statistical analysis showed that the most predictive variable related to the amount of canopy cover is the size of the city in hectares (acres). A combination of city population, hectares (acres) of tree cover, expenditures per capita on trees, and city size in hectares (acres) produced the greatest predictability in whether a city participates in the TCUSA program. The relationship between quantity of tree canopy and total population was stronger in participating than in nonparticipating communities. However, the relationship between land area and quantity of tree canopy was stronger for nonparticipants than for participants, and overall percentage of canopy cover as well as mean percentage of canopy cover were higher in nonparticipating communities. TCUSA participants in Maryland have similar land areas, similar ethnic demographics, higher populations, and canopy coverage more closely related to population than land area when compared to non-TCUSA communities and are most likely to be found in an urban/suburban context, while non-TCUSAs are more likely to be found in a rural (agricultural/forest) context.
\end{abstract}

Key Words. Tree City USA; tree canopy cover; demographics.

The Tree City USA (TCUSA) program is a cooperative program of the National Arbor Day Foundation (NADF), the USDA Forest Service (USDA-FS), and the National Association of State Foresters. The program provides recognition to communities that meet four standards in a given year: (1) Presence of a tree board or department legally responsible for care and management of a community's trees, (2) a community tree ordinance that designates the tree board or department as responsible for care and management of trees, (3) community forestry expenditures of at least US\$2.00 per capita, and (4) an Arbor Day observance and proclamation (Fazio 1992). The TCUSA Growth Award is a related recognition provided to communities for demonstrating higher levels of achievement in funding, planning and management, tree planting and maintenance, education and public relations, or partnerships in a given year (USDA Forest Service 2004).

In 2002, more than 3.9 million people in the state of Maryland, U.S., approximately $73.5 \%$ of the state population, lived in 42 jurisdictions recognized as TCUSA communities. These communities spent over US\$15 million on local urban and community forestry (UCF) programs.

According to NADF, benefits of TCUSA participation include publicity, public image, citizen pride, and education (Fazio 1992). The program provides an excellent opportunity for education and dissemination of information related to the benefits of trees. While the program requires establishment of a tree ordinance and existence of a tree board or department empowered by the ordinance supported by an annual budget of at least US $\$ 2.00$ per capita for tree management activities, it is not known whether the program results in a level of tree protection and enhancement that results in an increase in tree cover.

Maco and McPherson (2002) reported that quantity of tree canopy cover is related to quantity of tree benefits and that an increase in canopy provides a correlated increase in benefits such as energy savings; air, soil, and water quality improvement; carbon sequestration; stormwater management; and an increase in appraised real estate values.

The United States Code section that authorizes funding for the national UCF program reports that "... urban trees are 15 times more effective than forest trees at reducing the buildup of carbon dioxide and aid in promoting energy conservation through mitigation of the heat island effect in urban areas. ... Tree plantings ... in urban areas and communities can aid in reducing carbon dioxide emissions, mitigating the heat island effect, and reducing energy consumption, thus contributing to efforts to reduce global warming trends." Among the purposes of the UCF program are to "... improve understanding of the benefits of preserving existing tree cover in urban areas and communities, .. encourage owners of private residences and commercial properties to maintain trees and expand forest cover on their properties, ... [and] provide education programs and 
technical assistance to state and local organizations (including community associations and schools) in ... identifying appropriate tree species and sites for expanding forest cover" (U.S. Congress 2002).

The USDA Forest Service and partners have reviewed many programmatic items for potential applicability to a recent U.S. congressional directive to devise performancerelated criteria that will assist in determining state UCF funding allocations. Both the number of communities with tree ordinances in a state and the percentage of tree canopy cover in urban areas in a state have been discussed as potential partial criteria for allocation of UCF program funds to states within the USDA Forest Service Northeastern Area (Loucks 2002). In 2004, the National Association of State Foresters reported that funding allocations from the USDA Forest Service Washington office to various regions of the United States should be in part based on the number of TCUSAs in that region as a percentage of the total TCUSAs in the previous calendar year (USDA Forest Service 2004).

Because the U.S. Congress has made tree canopy cover a primary focus of the UCF program, and because TCUSA is being considered by the implementing agency (USDA-FS) as a fundamental and possibly required vehicle for program delivery, it is worthwhile to assess whether TCUSA may be useful in accomplishing UCF program tree canopy goals.

This paper sought to answer the following questions:

- Is there a relationship between tree canopy quantity and TCUSA participation?

- Are communities with certain ethnic demographic profiles more or less likely to participate in TCUSA?

- Are communities with land areas or populations above or below certain thresholds more or less likely to participate?

- What are the comparative characteristics, with regard to land area, tree cover, population, and demographics, between TCUSA and non-TCUSA participants in Maryland?

\section{METHODS}

Census 2000 Summary File 1 (U.S. Census Bureau 2001) 100-Percent Data for Maryland by Place was downloaded. Tab SF1 of the spreadsheet was copied to a new file. The following tables were used: Total Population; Race; and, Hispanic or Latino, and not Hispanic or Latino by Race.

Data from the USDA Forest Service on percentage of tree cover for urban places and places within urbanized areas in Maryland (Dwyer et al. 2000) were incorporated into the spreadsheet.

Because TCUSA recognition is granted to political subdivisions, all 211 census-designated places (CDPs; unincorporated areas) were deleted from the list. Of the remaining 157 places, the 83 for which no tree cover data were available (Dwyer et al. 2000) were deleted, leaving 74 incorporated places for which demographic and tree cover data were available. TCUSA participation data were available for 30 of these.

The 74 incorporated places were then assessed in three groupings: All incorporated places, all TCUSA participants, and all non-TCUSA participants.

Descriptive statistics were generated for data (Table 1). The Pearson's moment for all potential pairings of data was generated. A linear regression equation was used to calculate and graph the $r^{2}$ value for pairs of data sets.

Most of the data did not meet the requirements of a normal distribution. Therefore, nonparametric statistics were used where appropriate. Baltimore City is the largest single community in this analysis. It has approximately 600,000 more residents ( $48.7 \%$ of the total population among communities listed) and approximately 15,600 ha $(39,000 \mathrm{ac})$ more land area $(25.8 \%$ of the total land area among communities listed) than the next largest jurisdiction. Because of the potential to bias the results of the analysis, all comparisons were run twice, once including Baltimore City and the other excluding Baltimore City.

A multivariate stepwise regression analysis was run on the variables. All variables were subjected to the Omnibus Normality Test and the Modified-Levene Equal Variance Test (Hintze 1995). Because the demographic variables did not exhibit a normal distribution, a log transformation was used for counts and an arcsine transformation was used for percentages to stabilize variances (Snedecor and Cochran 1967). The all-possible regression computer program was used, which looks for the best model of the relationship between the supplied variables. A hierarchical clustering report was run on the results.

A GIS shapefile of Maryland municipalities was opened in ArcView and was reduced to include only the communities in the study. The attribute table was modified to include fields for canopy cover percentage, TCUSA participation, and cluster number based on the results of the hierarchical clustering report. The layer was then opened in iterations of classification based on the added fields noted to assess whether any spatial relationship existed related to those attributes.

\section{Table 1. Variables in the study.}

\begin{tabular}{lll}
\hline \multicolumn{2}{l}{ Description of variable } & Variable in model \\
\hline A & Total population & (Ln_total_Pop) \\
B & Tree cover & (LN_Tree_cvr) \\
C & Dollars per capita (TCUSAs) & (LN_Dollars_per_Cap) \\
D & City size & (LN_City_acres) \\
E & Population density & (LN_Pop_Density) \\
F & Percentage nonwhite population & (ArcSin_Nonwhite_prcnt) \\
G $\quad$ Percentage Hispanic population & (ArcSin_Hispanic_Prcnt) \\
H $\quad$ Percentage Black or & (ArcSin_B_AA_prcnt) \\
& African American population & \\
I & Cluster number & (Cluster_no_) \\
\hline
\end{tabular}




\section{RESULTS AND DISCUSSION}

\section{Population and Ethnic Demographics}

Among all communities, total population ranged from 109 (Highland Beach) to 651,154 (Baltimore City), with a mean of 18,065 and a median of 4,889. Population density per 0.4 ha $(1 \mathrm{ac}$ ) ranged from 1.45 (Brookeville) to 20.37 (Mount Rainier), with a mean of 5.85 and a median of 4.99. There was no significant correlation between total population and population density, or between total population and the percentage of tree cover. The total nonwhite population in the communities is $51.51 \%$, with the majority $(85.93 \%$ ) of those being Black or African American, and with 8.06\% being Hispanic.

The larger the population, the more likely the jurisdiction is to participate in TCUSA (Figure 1). There is a statistically significant relationship between the total population and participation in the TCUSA program (chi-square $=$ 19.331775, degrees of freedom $=5$, probability level $=$ 0.001667).

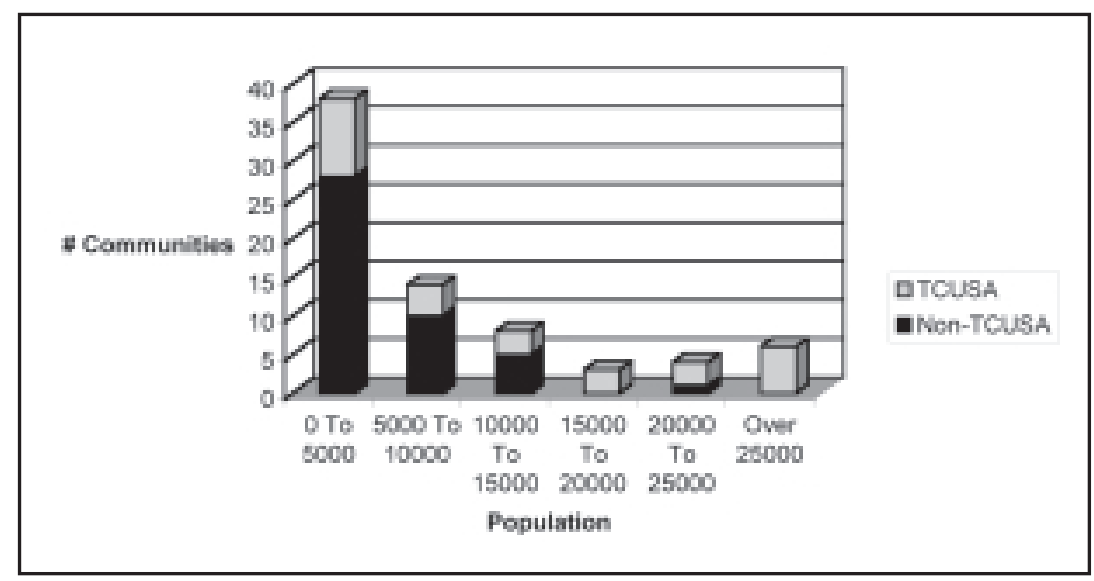

Figure 1. Tree City USA participation by population.

\section{Land Area and Tree Cover}

Various methods for quantifying canopy cover exist. Different data sources and methods will produce results of varying accuracy. Marey et al. (2003) reported that source data and method of photo interpretation for land use classification should be based on the resources available and the resolution required to provide accurate information at a given scale and concluded, "When making thematic mapping, the first step is to consider the objectives of the study, then test the procedures and select the proper model and, finally, analyze the results in some sample areas before applying it to the whole study area."

The Maryland UCF program has worked with various data sources and methods for quantifying canopy cover, including the USDA-FS source identified here, interpretation of digital orthophotoquad (DOQ) maps [1 m (3.3 ft) ground resolution, quarter-quadrangle (3.75" of latitude by $3.75 "$ of longitude]) using a random plot generator and a "click and classify" ArcView extension, and application of the ERDAS Imagine Resolution Merge to IKONOS satellite imagery [4 m (13.2 ft) multi-spectral, $1 \mathrm{~m}$ (3.3 ft) panchromatic] to produce land cover "masks" for trees and nontree vegetation (Irani and Galvin 2003). While the data resolution and methods noted here vary, we used the USDA-FS canopy data for two primary reasons: It was the most complete canopy cover data source for Maryland communities available at the time of the analysis, and it is a national data set that would allow similar assessments to be conducted in other states and compared with our results.

Land area within jurisdictions studied ranged from 17.0 ha (42.4 ac) in Highland Beach to 20,685.9 ha (51,714.8 ac) in Baltimore City. Quantity of tree canopy cover ranged from $3.3 \mathrm{ha}$ (8.3 ac) in Walkersville to 4,550.9 ha (11,377.3 ac) in Baltimore City. Percentage tree canopy cover ranged from $0.3 \%$ (Walkersville) to $76.4 \%$ (Havre de Grace). The most predictive variable in the study related to tree cover is the size of the city in hectares (ac). Dropping the variable for tree cover reduced the percentage of variation accounted for by the model to $19.5 \%$.

\section{TCUSA Communities vs. Non-TCUSA Communities}

A combination of city population, hectares (ac) of tree cover, expenditures per capita on trees, and city size in hectares (ac) produces the greatest predictability in whether a jurisdiction participates in the Tree City USA program. This combination accounts for $91.6 \%$ of the variation among cities in terms of participation (Table 2). Forcing the inclusion of the demographic variables from the census data actually degrades the predictability of the model.

Figure 2 indicates the number of TCUSAs by city size in hectares (ac). The results indicate that there is no threshold of city size that differentiates between the participants and nonparticipants in the TCUSA program (chi-square $=4.304927$, degrees of freedom $=2$, probability level $=0.116198$ ). The probability of obtaining this distribution by random sampling of a population with no true difference is 0.116 . There is no relationship between land area and participation. Baltimore City was omitted from this analysis, but if it had been included, the results would not have changed.

The relationship between land area and total population was stronger for all TCUSA communities, excluding Baltimore, than for the non-TCUSA communities. The relationship between quantity of tree cover and total population was also stronger for all TCUSA communities, except Baltimore, than for the non-TCUSA communities (Figures 3 
Table 2. Results of analysis for best model.

\begin{tabular}{llccl}
\hline Model size & $r^{2}$ & Root MSE & Cp & Model \\
\hline 8 & 0.916272 & 6.081158 & 8 & ABCDFGHI \\
8 & 0.916272 & 6.081158 & 8 & ABCEFGHI \\
8 & 0.916272 & 6.081158 & 8 & BCDEFGHI \\
8 & 0.916122 & 6.086612 & 8.0359 & ABCDEFHI \\
8 & 0.913705 & 6.173691 & 8.61329 & ABCDEFGI \\
8 & 0.91319 & 6.192088 & 8.73632 & ABDEFGHI \\
8 & 0.912655 & 6.211124 & 8.86402 & ABCDEGHI \\
8 & 0.909295 & 6.329459 & 9.6666 & ABCDEFGH \\
8 & 0.909295 & 6.329459 & 9.6666 & ABCDEFGH \\
8 & 0.195808 & 18.84655 & 180.097 & ACDEFGHI \\
\hline
\end{tabular}

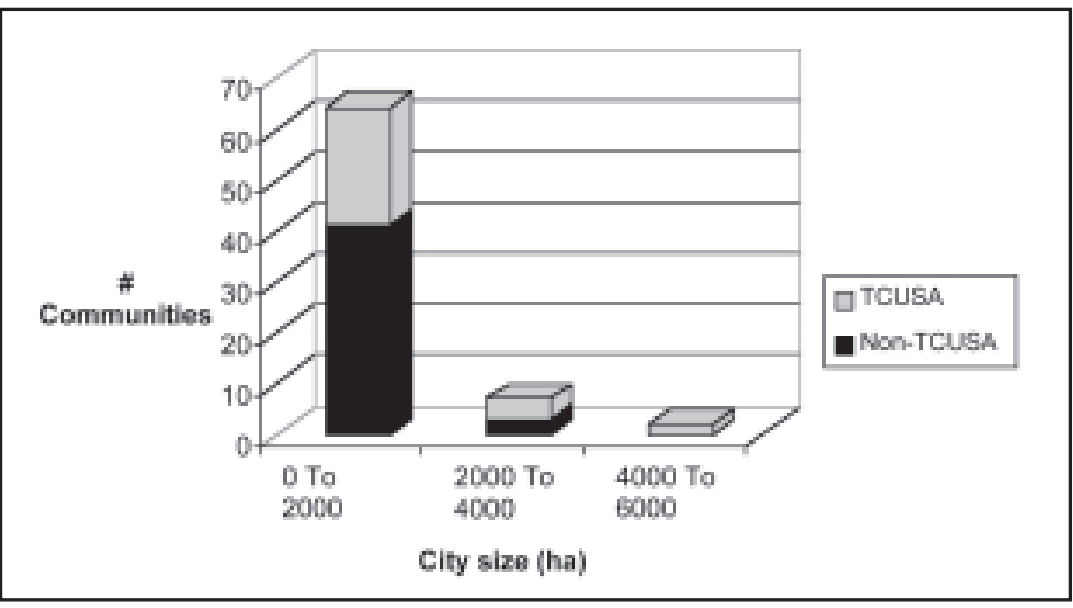

Figure 2. TCUSA participation by city size (ha).

and 4). However, the relationship between land area and quantity of tree cover was stronger in the non-TCUSA communities (Figures 5 and 6) than in the TCUSA communities, excluding Baltimore.

TCUSA per capita spending for all participating communities, excluding Baltimore, was not significantly correlated to any of the other fields. Overall TCUSA spending related similarly to both total land area and population but was not strongly related to quantity of tree cover.

The total nonwhite population in TCUSA communities, excluding Baltimore, was 165,825 , with a mean of 5,718 per jurisdiction and a range of 26 (Chevy Chase Section Five) to 21,988 (Gaithersburg). Nonwhite population as a percentage of total population in those communities had a mean of $35.6 \%$, with a range of 2.2\% (Hampstead) to 97.9\% (Seat Pleasant).

The nonwhite population of the non-TCUSA communities was 77,603 , with a mean of 1,764 per jurisdiction and a range of 3 (Brookeville) to 9,329 (Salisbury). Nonwhite population as a percentage of total population in these communities had a mean of $39.9 \%$, with a range of $2.2 \%$ (Funkstown) to 99.1\% (Glenarden).

The hierarchical cluster analysis grouped communities according to similarity among the variables studied and resulted in identification of six clusters. Clusters were significantly different (chi-square $=19.59$; degrees of freedom $=6$; probability level $=0.003$ ). Three communities were dissimilar from all others (Baltimore, Highland Beach, Walkersville) and were not assigned to any cluster.

Ninety-two percent of the 13 communities in Cluster 3 were TCUSAs. No other cluster had more than 50\% TCUSA participation. Cluster 3 communities were spatially located in the state's primary urban area (Figure 7) and were in the urban/suburban areas surrounding the District of Columbia and Baltimore in the piedmont and western coastal plain physiographic provinces.

Cluster 4 was the largest cluster (24 communities) and was dominated by nonTCUSAs (75\%). Cluster 4 communities were for the most part spatially located outside the Baltimore-Washington corridor and were surrounded by predominantly rural (forest, agricultural) land uses in the coastal plain (eastern shore, southern Maryland), piedmont, and mountains (western Maryland).

\section{CONCLUSIONS}

There is no relationship between participation in TCUSA and ethnic demographics. Both participating and nonparticipating communities have demographics ranging from $2.2 \%$ nonwhite to greater than $97.0 \%$ nonwhite. The TCUSA communities we studied had larger populations and larger nonwhite populations than non-TCUSA communities, with the mean percentage nonwhite population higher for nonparticipants.

There is no threshold of city size that differentiates between the participants and nonparticipants in the TCUSA program. While we did find a significant relationship between population and participation in TCUSA (the larger a jurisdiction's population, the more likely it is to participate), we did not find a threshold for participation. Of the communities studied, $92.3 \%$ with populations above 15,000 participated in TCUSA, while only $28.3 \%$ of communities with populations below 15,000 participated. In many smaller communities in Maryland there is no staff person or department legally responsible for care and management of a community's trees. This situation makes recruitment and continued participation more difficult for small communities and may require additional investments by the state forestry agency. While state urban forestry programs may find interest for the Tree City USA program in communities regardless of population or land area, we found participation is increasingly likely for communities with larger populations.

The overall percentage of tree canopy cover was higher for non-TCUSA communities (34.55\%) than for TCUSA 


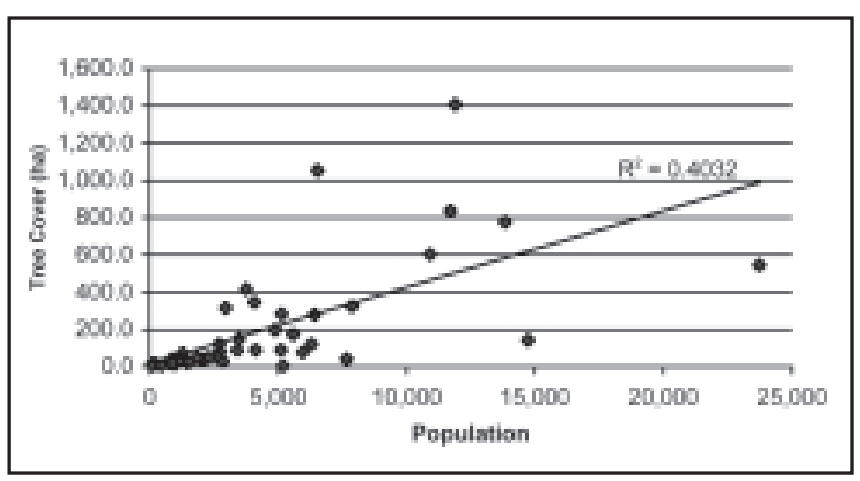

Figure 3. Relationship between tree cover and population for non-TCUSA communities.

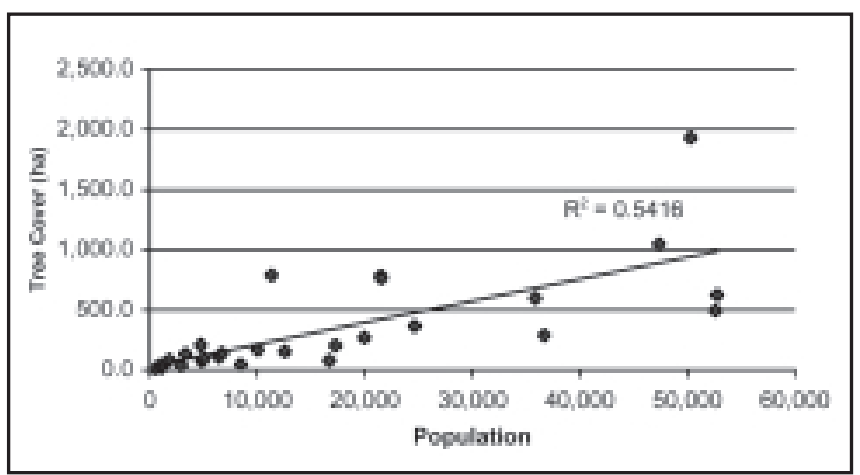

Figure 4. Relationship between tree cover and population for TCUSA communities, excluding Baltimore.

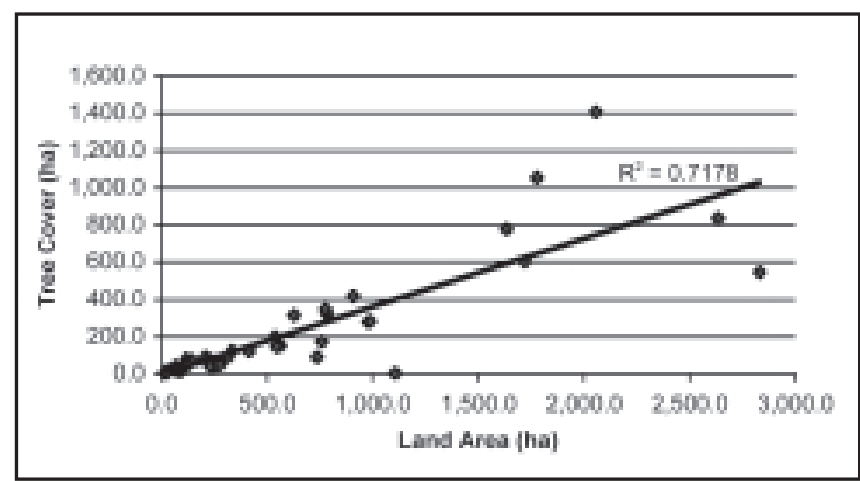

Figure 5. Relationship between tree cover and land area for non-TCUSA communities.

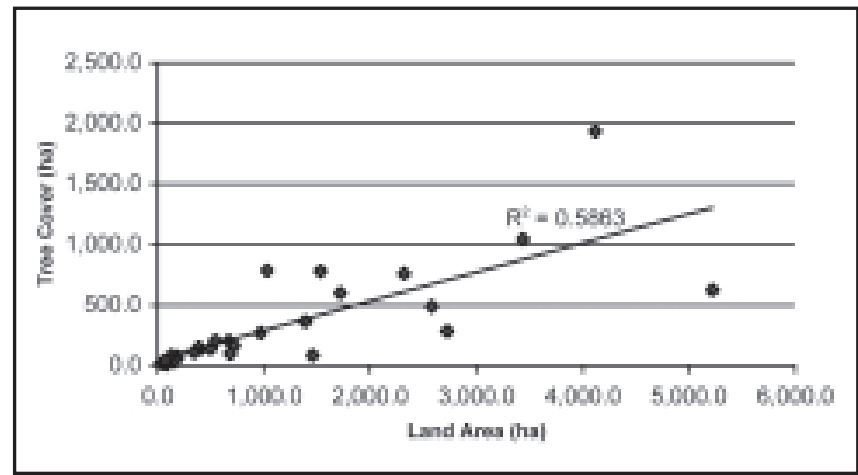

Figure 6. Relationship between tree cover and land area for TCUSA communities, excluding Baltimore.

communities (25.98\%), and the mean percentage of tree canopy cover was slightly higher in non-TCUSA communities (36.96\%) than in TCUSA communities (32.78\%). Cumming et al. (2001) found that a statewide Maryland ordinance pertaining to roadside trees protected the quality but not the quantity of subject trees. While no qualitative information was used in the present study, it similarly found that the presence of an ordinance did not relate to a higher quantity of trees. The non-TCUSA communities in this study had higher mean tree cover than the TCUSA communities, all of which have tree ordinances. Results indicate that there is an increasing interest in TCUSA where resource and population pressures are greatest (i.e., where there are increasing numbers of people and decreasing numbers of trees). In non-TCUSA communities,

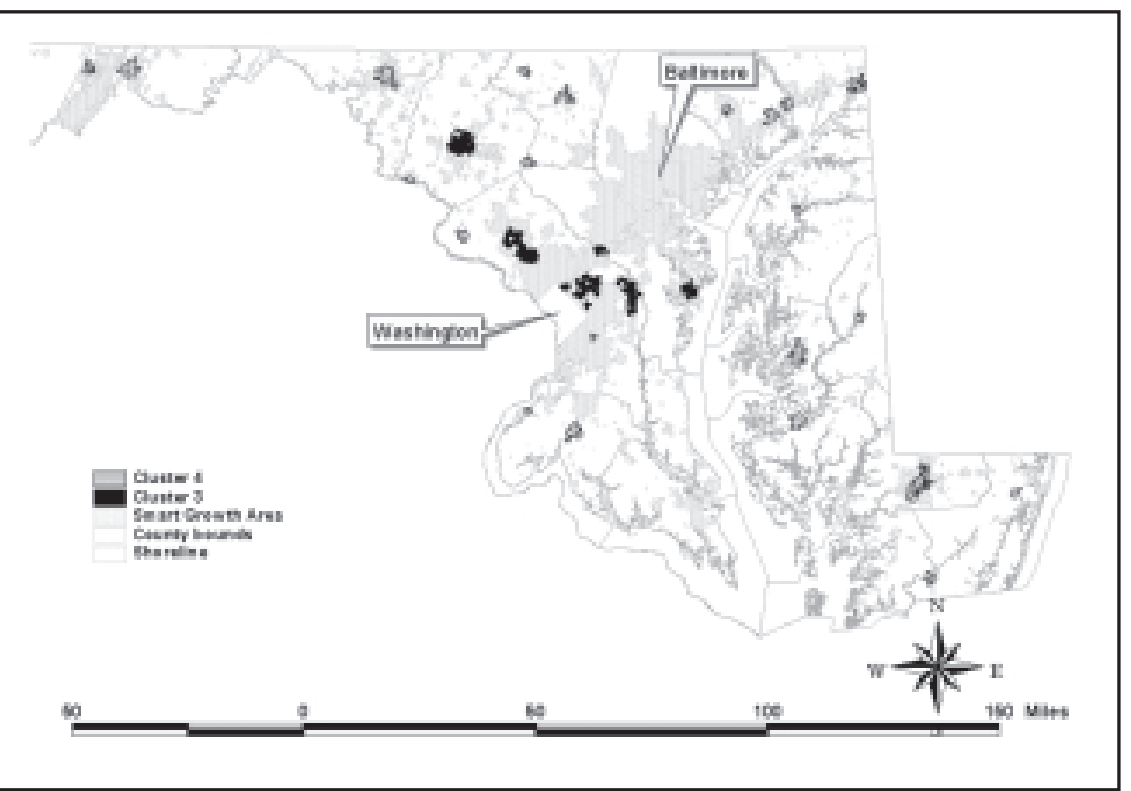

Figure 7. Spatial distribution of Cluster 3 and Cluster 4 communities. canopy cover was most closely related to the amount of land area. However, for TCUSA communities, the amount of canopy coverage was most closely related to

population. This correlates to the NADF's assertion of TCUSA benefits. The TCUSA program in Maryland has a 
more direct relationship to people (awareness, pride, etc.) than resources (quantity of canopy cover).

TCUSA participants in Maryland have similar land area, similar ethnic demographics, and higher populations, with canopy coverage more closely related to population than to land area when compared to non-TCUSA communities. TCUSA communities are most likely to be found in an urban/ suburban context, while non-TCUSA communities are more likely to be found in a rural (agricultural/forest) context.

This study did not consider the type of ordinance (street trees, public trees, all public and private trees, etc.) because this information is not part of TCUSA submission. Such differences may, however, be a factor in current canopy cover disparities.

This study did not consider the number of years a TCUSA community has participated in the program. For new participants with a street tree ordinance, the primary objective in the first years of the program may be risk tree assessment and management, which could result in an initial decline in canopy cover until replacement trees mature.

\section{RECOMMENDATIONS}

We recommend that other states undertake similar research to determine what relationships exist among tree canopy quantity, community demographics, and TCUSA program participation in those jurisdictions. Our sample size was quite small due to the relatively small number of municipalities in Maryland. The Washington-Baltimore Metropolitan Statistical Area is the fourth largest in United States and is home to more than 7.2 million people. Maryland ranks fifth among the 50 states in population density. Results from less urban states may be notably different.

Communities wishing to increase canopy cover should draft ordinances specifically directed to accomplish that objective because tree ordinances studied did not result in higher canopy cover among communities studied.

As evidenced by tree ordinances supported by expenditures of US $\$ 2.00$ or more per capita, there is considerable interest and support for UCF activities in communities of varying social demographics. Public agency UCF staff should engage communities of all demographic groups to facilitate equitable management of urban natural resources.

\section{LITERATURE CITED}

Cumming, A.B., M.F. Galvin, R.J. Rabaglia, J.R. Cumming, and D.B. Twardus. 2001. Forest health monitoring protocol applied to roadside trees in Maryland. J. Arboric.

27:126-137.

Dwyer, J.F., D.J. Nowak, M.H. Noble, and S.M. Sisinni. 2000. Connecting People with Ecosystems in the 21st Century: An Assessment of Our Nation's Urban Forests. Gen. Tech. Rep. PNW-GTR-490. USDA Forest Service Pacific Northwest Research Station, Portland, OR. 483 pp.
Fazio, J.R. (Ed.). 1992. Tree City USA: Foundation for Better Tree Management. Tree City USA Bulletin No. 22. National Arbor Day Foundation, Nebraska City, NE. 8 pp.

Hintze, J.L. 1995. Number Cruncher Statistical Systems (software documentation). Kaysville, UT.

Irani, F.W., and M. F. Galvin. 2003. Strategic urban forests assessment: Baltimore, Maryland. In Proceedings from the American Society of Photogrammetry and Remote Sensing 2003 Annual Conference, "Technology: Converging at the Top of the World."

Loucks, P. 2002. Northeastern Area Urban Forestry Coordinators Organization fact sheet to the Northeastern Area Association of State Foresters regarding recommendations on the federal fiscal year 2002 and 2003 UCF allocation formulas. Unpublished.

Maco, S.E., and E.G. McPherson. 2002. Assessing canopy cover over street and sidewalks in street tree populations. J. Arboric. 28:270-276.

Marey, M., U. Fra, and R. Crecente. 2003. Cost analysis of the application of various photointerpretation techniques to land use classification. American Congress on Survey and Mapping 2003 Conference papers. www.acsm.net/RemoteSensingAnalysis42.pdf (accessed 9/15/04).

Snedecor, G.W., and W.G. Cochran. 1967. Statistical Methods. Iowa State University Press, Ames, IA.

U.S. Census Bureau. 2001. Census 2000 Summary File 1 (SF 1). factfinder.census.gov/servlet/DatasetMainPageServlet? ds_name=DEC_2000_SFl_U\&_program $=$ DEC\&_lang=en (accessed 9/15/04).

US Congress. 2002. 16 US Code 2105. uscode.house.gov/ uscodecgifastweb.exe?getdoc+uscview+t13t16+6957+1++\% 2528 urban\%20and\%20community\%20forestry\%2529 (accessed 9/15/04).

USDA Forest Service. 2004. Urban and Community Forestry Allocation Workgroup, allocation alternative \#2, NASF Modified. 6 pp.

Acknowledgments. The authors would like to thank Anne Buckelew Cumming, urban forester, USDA Forest Service, for her review and comment on the initial manuscript.
${ }^{1 *}$ Supervisor, Urban \& Community Forestry, Maryland Forest Service
${ }^{2}$ Data Analyst, Watershed Management $\&$ Analysis, Chesapeake $\&$ Coastal Watershed Service
Maryland Department of Natural Resources
580 Taylor Avenue
Annapolis, MD 21401, U.S.
*Corresponding author. 
Zusammenfassung. Das amerikanische Programm zur Stadt der Bäume (TCUSA) ist ein nationales Programm, welches Anerkennung für Kommunen bereitstellt, die bestimmte Voraussetzungen, wie z.B. eine +Baumverordnung, erfüllen und pro Einwohner mindestens \$US 2,00 für städtische Forstwirtschaft ausgeben. Die Daten der Volkszählung von 2000 wurden mit den Aufzeichnungen von TCUSA und den Daten zur Baumkronenbedeckung in 74 Gemeinden in Maryland verbunden, um die Beziehungen zwischen Baumkronenmenge, Bevölkerungsdemographien und der Teilnahme an dem TCUSA zu verstärken. Die an dem TCUSA teilnehmenden Gemeinden hatten weit gestreute Demographien von 2,2\% bis über mehr als $97 \%$ nicht weiß, aber sie tendierten eher zu großen gemischten Populationen und größeren nicht-weißen Populationen als Nicht-Teilnehmer, mit einem Prozentsatz von etwas höheren nicht-weißen Populationen gegenüber Nichtteilnehmern. Eine multivariable statistische Analyse zeigte, dass die meistvorhersehbare Variable in Bezug auf die Kronenbedeckung die Größe der Stadt in Hektar ist. Eine Kombination von Stadtbevölkerung, Anzahl der Hektar der Baumbedeckung, Prokopfausgaben pro Baum und die Stadtgröße in Hektar produzierte die größte Vorhersage in Bezug auf eine Aussage über die Teilnahme an TCUSA oder nicht. Die Beziehungen zwischen Menge der Baumbedeckung und der Menge an Baumkronen war bei Nichtteilnehmern stärker als bei den Teilnehmern und der generelle Anteil an Baumbedeckung und auch die durchschnittliche Baumbedeckung waren größer in nicht-partizipierenden Gemeinden.

Resumen. Tree City USA (TCUSA) es un programa nacional en los Estados Unidos que proporciona reconocimiento a las comunidades que reúnen ciertos estándares como contar con una normatividad para los árboles y gastar al menos US $\$ 2.00$ dólares per cápita en dasonomía urbana. Los datos del censo para el 2000 fueron combinados con los registros del programa de participación TCUSA y los datos de la cobertura arbórea para 74 comunidades en Maryland con el fin de averiguar las relaciones entre cantidad de cobertura arbórea, demografía poblacional y el programa de participación Tree City USA. Las comunidades participantes tuvieron amplias variaciones demográficas (2.2\% a más de $97 \%$ de población no blanca), pero tendieron a tener mayores poblaciones totales y mayores poblaciones no blancas que los no participantes, con el porcentaje de población no blanca levemente más alto que los no participantes. Un análisis estadístico multivariado mostró que la variable con mayor poder de predicción relacionada con la cantidad de cobertura es el tamaño de la ciudad en hectáreas. Una combinación de: población citadina, cobertura en hectáreas, gasto en árboles per cápita, y tamaño de la ciudad en hectáreas produjo la predicción más grande, estén o no en el Programa TCUSA. La relación entre cantidad de cobertura arbórea y población total fue más fuerte en las comunidades participantes que en las no participantes. Sin embargo, la relación entre área superficial y cantidad de cobertura arbórea fue más fuerte para los no participantes que para los participantes, y el por ciento total de cobertura así como la cobertura media fueron más altos en las comunidades no participantes.

Résumé. Le programme pour les arbres dans les villes Tree City USA (TCUSA) est un programme national aux ÉtatsUnis qui fournit une certaine reconnaissance aux municipalités rencontrant certaines normes, incluant d'avoir une ordonnance pour les arbres et un budget de dépense d'au moins $2 \$$ per capita en foresterie urbaine. Des données de recensement de l'an 2000 ont été combinées avec des données de participation au programme TCUSA ainsi que des données sur la couverture arborée de 74 communautés du Maryland afin de vérifier les relations entre le degré de couverture arborée, la démographie et le degré de participation au programme TCUSA. Les communautés participantes étaient très variables en termes démographiques (de 2,2\% à $97 \%$ de non blancs), mais tendaient à avoir des populations plus vastes et des populations de non blancs plus vastes que celles des participants, et ce avec un pourcentage de non blancs légèrement plus important pour les non participants. Des analyses de multi-variances statistiques ont montré que la meilleure variable de prédiction en relation avec la couverture arborée était la taille de la ville en hectares. Une combinaison des variables suivantes a permis de dégager les meilleures prédictions par rapport à savoir si une ville allait participer ou non au programme en question, soient: population de la ville, nombre d'hectares de couverture arborée, dépenses per capita sur les arbres, superficie de la ville en hectares. La relation entre le degré de couverture arborée et la population totale était plus forte dans les communautés participantes que celles non participantes. Quoiqu'il en soit, la relation entre la superficie de la ville et le degré de couverture arborée était plus forte chez les communautés non participantes que les participantes, et le pourcentage global de couverture arborée tout comme le pourcentage moyen de couverture arborée étaient plus élevés chez les communautés non participantes. 